\title{
НАЗИВИ ЖИВОТИЬА У ФУНКЦИЈИ НОМИНАЦИЈЕ ЧОВЕКА ПРЕМА ДРУШТВЕНОЈ УЛОЗИ У ЖАРГОНУ СРПСКОГ ЈЕЗИКА $* *$
}

\begin{abstract}
Предмет рада јесу називи животиња и њихови деривати којима се, у жаргонском регистру, у секундарној семантичкој реализацији реферише на човека као представника одређене професије, друштвеног положаја или националности. Основни циљ рада јесте да на лексичкој грађи, сакупљеној из речника̂ српскога језика, жаргонских речника и из електронског корпуса, утврдимо све релевантне лексичке механизме који доводе до преноса номинације са животиње на човека као социјално биће и класификујемо грађу према семантичком критеријуму. У истраживање укључујемо и лингвокултуролошке аспекте који треба да рефлектују аксилошке ставове српске лингвокултуролошке заједнице према представницима одређених животиња и човеку као носицу одређених друштвених улога.

Кључне речи: називи животиња, жаргон, српски језик, друштвена улога.
\end{abstract}

\section{1. Предмет рада и циљеви}

1.1. Предмет нашег рада јесу називи животиња који у примарној семантичкој реализацији денотирају представнике различитих животињских врста, а у секундарној реферишу на човека као носиоца одређене професије, друштвеног положаја/статуса или националности, претежно у жаргонском регистру. Као примарни циљ рада одредили смо успостављање што обухватније лексичке грађе коју смо, због природе реализације ових семема претежно у публицистичком регистру, ексцерпирали из жаргонских речника српског језика - Двосмерног речника жаргона и жаргону сродних речи и израза

*slobodan.novokmet@isj.sanu.ac.rs

** Рад настао је у оквиру пројекта 178009 Лингвистичка истражсивања савременог српског књижевног језика и израда Речника српскохрватског књижевног и народног језика САНУ, који у целини финансира Министарство просвете, науке и технолошког развоја Републике Србије. 
Д. Андрића (РЖ) и Речника српског жаргона Б. Герзића (РСЖ). Корпус смо допунили грађом из Речника српскохрватског књижевног и народног језика (РСАНУ) и Речника српскога језика (РСJ), и потврдили, где је то могуће, примерима из електронског корпуса српског језика - Корпус савременог српског језика (СрпКор2013). ${ }^{1}$ Секундарни циљ је утврђивање релевантних лексичких механизама који доводе до преноса номинације са животиње на човека као социјално биће и представника одређене друштвене групе, те испитивање природе мотивације која је у основи тих преноса. С тим у вези, у истраживање смо укључили и лингвокултуролошки аспект, који треба да нам покаже аксиолошке ставове српске лингвокултуролошке заједнице, с једне стране, према представницима одређених животињских врста, и, с друге, према човеку као носицу маркираних друштвених улога, насталим као последица међуљудских односа у друштву. Испитали смо разлоге због којих се зооними у супстандардној језичкој реализацији користе за изражавање става повишене афективне вредности према носиоцима извесних социјалних група и зашто се они, на тај начин, подвргавају критици.

\section{2. Уводна разматрања}

2.1. У лингвокултуролошким истраживањима и радовима који су претходили овом, утврђено је како је суживот човека и животиње, те подређен однос животињског света у односу на човеков, у српској језичкој заједници резултирао махом негативним односом према одређеним животињама или групама животиња (в. Ристивојевић/Рајковић 2008, 2014; Ранђеловић 2012; Новокмет 2016, 2017), што се на језичком плану одразило и на различито конотиране лексичке потенцијале зоолошких лексема. Животињско царство, како се истиче у досадашњим истраживањима, једно је од најмоћнијих извора пројектовања, махом стереотипних, особина животиња на особине људских бића (Кјелтика/Клепарки 2005: 86), од чега се посебно издвајају људске карактерне особине у које убрајамо и интелигенцију, карактер, емотиван живот, сексуалност и сл. (нпр. гуска/кокошка/ћурка - глупа женска особа; свиьа/цукела - неморална особа и сл.).

2.2. Полазна лексема у својој семантичкој структури обично има компоненту засновану на колективној експресији, колективном схватању да одређена животиња има какву особину која је својствена човеку или се може приписати човеку (Гортан Премк 2004: 107). Семе колективне експресије носе у себи различите екстралингвистичке и национално предодређене садржаје о томе како се тај појам оцењује и прихвата у друштву. Оне се темеље на искуству и суживоту с различитим животињама, али могу бити и резултат устаљеног доживљаја животињског понашања, који се махом ослања на културолошке предрасуде, представљајући значајан елемент антропоцентрич-

\footnotetext{
${ }^{1}$ Корпус савременог српског језика који се израђује на Математичком факултету у Београду (JeRTeh - Друштво за језичке технологије и ресурсе).
} 
ног погледа на животињски свет (нпр. домаће птице су мање интелигентне и „брбљиве”, свиње прождрљиве и „неморалне” и сл.). Као кључне полазне поддомене концепта одређене животиње који се преносе на човека, поред сема колективне експресије, треба издвојити и њихову величину, станиште, изглед, понашање и однос са људима (различити аспекти друштвене корисности одређене животиње са становишта језичке заједнице) (в. Вјежбицка 1985, Мартса 1999).

\section{3. Теоријска разматрања}

3.1. Негативни ставови према неким животињама, карактеристични за наивну слику света, могу дати објашњење често дерогативне употребе зоонима у комуникативним ситуацијама, чиме се потврђује закључак пређашњих истраживања о томе како је зоонимска метафора учестало средство експресивног истицања непожељних људских карактеристика. Лопез Родригезова, посматрајући зоонимске метафоре као увид у конструкцију социјалних идентитета, подсећа да се преко њих могу истаћи социјалне и етничке разлике (Лопез Родригез 2009). Негативно конотиране зоонимске метафоре, према теорији Великог ланца постојања, ${ }^{2}$ имају улогу ниже вредносне категоризације маргиналних група као што су хомосексуалци, имигранти или жене, док се „лингвистичка ксенофобија” испољава називима као што су нпр. жабари (енгл. frogs) за Французе у Британији (Лопез Родригез 2009: 79). Ауторка каже да такође није необично што се у енглеском и шпанском језику мушкарци чешће поистовећују са животињама веће величине и онима које живе у дивљини (бик или вук), док се жене чешће виде као мале домаће животиње (нпр. кокошка). ${ }^{3}$ Иако блиске човеку, животиње као што су пас и мачка (чак и у својим хипокористичким облицима у енглеском - pussy, kitten, puppy) често се конотативно доводе у везу са промискуитетном женом. ${ }^{4}$ Слична конотација у енглеском језику у вези је са називима мањих пти-

\footnotetext{
${ }^{2}$ Према појмовној хијерархији ове теорије, људи имају особине и понашање вишег степена и одликује их рационално мишљење, док животиње располажу само инстинктивним понашањем.

${ }^{3}$ Оваквом поделом између мушкараца и жена може се наслутити каква је улога наметнута женама од стране друштва - ситне домаће животиње са којима се углавном поистовећују жене упућују на то да женска улога у друштву треба да буде ограничена на кућу и домаћинство, док мушкарци, будући повезивани са дивљим животињама, треба да буду слободни и без граница (Лопез Родригез 2009: 83).

Наравно, величина животиње (тј. њен физички изглед) овде је само један од неколико параметара који утичу на контекстуализацију животиње у одређеној култури, у које убрајамо и њен положај у религији, фолклору, литератури (нпр. басне), начин храњена, станиште, односа човека према њој и сл. Тако се изразито ситне животиње, као што су црв или мрав, могу односити и на мушкарца и на жену истичући негативне карактерне особине; неке изразито крупне животиње, као што су пастув или бик, могу се односити на мушкарце позитивних особина (снажни и потентни) и сл.

${ }^{4}$ Ову појаву у шпанском и енглеском језику Лопез Родригезова покушава да елаборира преко Личовог (Лич 1964: 42-45) објашњења везе између животињских назива и табуа. Личова карактеризација животиња почива на двама параметрима: сочијална дистанцุа и јестивост. По
} 
ца, као што су папагај или канаринац, а оглашавање птица доводи се у везу са женама које много причају (2009: 86-87). ${ }^{5}$ С друге стране, виђење жена као домаћих, сеоских животиња (крава, кобила и сл.) доводи се у везу са њиховом биолошком и репродуктивном улогом (И. 87), док се повезивање са неким другим животињама у српској култури, пре свега из категорије птица, као што су кокошка, гуска, ћурка, пре доводи у везу са њиховим социјално улогама и интелектуалним капацитетима, тј. тако се номинују брбљиве или мање интелигентне женске особе.

\section{4. Анализа грађе}

4.1. Примере у раду издвојили смо из лексикографских извора лексичко-семантичком анализом лексикографских дефиниција секундарних семантичких реализација зоонима које се односе на човека, маркирајући у оквиру дефиниција квалификације које се тичу његовог друштвеног положаја.

\begin{tabular}{|c|c|}
\hline $\begin{array}{c}\text { Социјалне групе или носиоци } \\
\text { одређених занимања }\end{array}$ & $\begin{array}{c}\text { Зооними у функцији номинације друштвених } \\
\text { улога }\end{array}$ \\
\hline ПРИПАДНИЦИ ПОЛИЦИЈЕ & $\begin{array}{l}\text { ала }{ }^{6} \text { (полицијски инспектор, РЖ), гавран (ми- } \\
\text { лиционар, РЖ), глодар (милиционар, РЖ), кер } \\
\text { (милиционар, полицајац, РЖ/РСЖ), кераваи } \\
\text { (позорник који води пса, РЖ), кобаи (поли- } \\
\text { цијски инспектор, РЖ), кртица (обавештајац } \\
\text { убачен у туђе редове, РЖ), }{ }^{8} \text { иукела (милици- } \\
\text { онар, РЖ), пас (полицијски агент, РЖ/РСЈ), } \\
\text { ластавица (полицајка, шпијун, РЖ), лисаи } \\
\text { (линијски милиционар, РЖ) }\end{array}$ \\
\hline $\begin{array}{l}\text { ПРИПАДНИЦИ } \\
\text { КРИМИНАЛНИХ ГРУПА }\end{array}$ & $\begin{array}{l}\text { ајкула (шеф криминалистичког одељења, РЖ), } \\
\text { зверка (моћан криминалац, РСЖ), мрав (си- } \\
\text { тан препродавац дроге, РЖ/РСЖ), мазга/мула } \\
\text { (особа која преноси дрогу, РСЖ), паук (лих- } \\
\text { вар, зеленаш, РЖ), пацов (потказивач, РЖ/ } \\
\text { РСЖ), птичица (преступник, РЖ), скакавац } \\
\text { (провалник, потрчко, РЖ/РСЖ) }\end{array}$ \\
\hline
\end{tabular}

њему, постоји структурална коресподенција између начина на који се жене класификују као потенцијални сексуални партнери и начина на који се животиње посматрају као јестиве или нејестиве. Чињеница да се пас и мачка доводе у везу са женом која је промискуитетна може да значи да се у тим називима крије порука о незаконитом односу (Лопез Родригез 2009: 84).

${ }^{5}$ У српском језику то би биле нпр. чавка, сврака, док се женско „брбљање” може поистоветити и са кокошкама.

${ }^{6}$ У наш корпус убрајамо и митолошка бића као што су ала и аждаја, које имају зооморфне карактеристике.

${ }^{7}$ Već se bilo okupilo pedesetak svedoka koji su počeli da protestuju i policiji govore kerovi (Politika, 29.01.2001). (СрпКор2013)

${ }^{8}$ Glavni lik je pripadnica CIA Evelin Solt (Džoli), koja iznenada biva optužena da je ruski špijun - krtica (rts.rs, 5.8.2010). (СрпКор 2013) 


\begin{tabular}{|c|c|}
\hline $\begin{array}{l}\text { ЗАТВОРЕНИЦИ И ЗАПОС- } \\
\text { ЛЕНИ У КАЗНЕНИМ УСТА- } \\
\text { НОВАМА }\end{array}$ & $\begin{array}{l}\text { зебра (затвореник, РЖ), канаринаи, (затворе- } \\
\text { ник, онај који све открије полицији, РЖ/РСЖ), } \\
\text { кербер (строги чувар, РЖ/РСЈ/РСЖ), курјак } \\
\text { (затворски стражар, РЖ) }\end{array}$ \\
\hline ПРИПАДНИЦИ ВОЈСКЕ & $\begin{array}{l}\text { гуја (млад војник, неискусан, РЖ/РСЖ), галеб } \\
\text { (блажи војни старешина, РЖ), гуштер (млад } \\
\text { војник, новајлија, РЖ/РСЖ), }{ }^{9} \text { комарац (слаб } \\
\text { војник, РЖ), орао (строг војни старешина, РЖ) }\end{array}$ \\
\hline ПРОСТИТУЦИЈА & $\begin{array}{l}\text { буба (проститутка, РЖ), глодарка (полегуша, } \\
\text { РЖ), кока (проститутка, РЖ), галеб (подводач, } \\
\text { жиголо, РЖ), чавка (проститутка, РЖ), сова } \\
\text { (проститутка, РЖ), ицица (проститутка, РЖ) }\end{array}$ \\
\hline ШКОЛСКИ НАСТАВНИЦИ & $\begin{array}{l}\text { аждаја (строг наставник, РЖ), звер (строг на- } \\
\text { ставник, РЖ) }\end{array}$ \\
\hline $\begin{array}{l}\text { ПРИПАДНИЦИ } \\
\text { ОБЕЗБЕЂЕЊА }\end{array}$ & $\begin{array}{l}\text { горила (телохранитељ, РЖ/РСЈ), }{ }^{10} \text { мајмун } \\
\text { (телохранитељ, РЖ), булдог (телохранитељ, } \\
\text { РСЖ) }\end{array}$ \\
\hline НАЦИОНАЛНОСТИ & $\begin{array}{l}\text { делфин (ватерполо репрезентативац Србије, } \\
\text { СН), орлови (репрезентативци Србије у фуд- } \\
\text { балу, СН) }\end{array}$ \\
\hline ОСТАЛО & $\begin{array}{l}\text { ајкула (брокер, СН), }{ }^{11} \text { глодар (клошар, РСЖ), } \\
\text { жаба (ронилац, РЖ), кенгур (поштар, РЖ), } \\
\text { овца (човек одан богу, РСАНУ), бубамара } \\
\text { (девојка фудбалера, РЖ), папагај (радио-води- } \\
\text { тељ, РЖ), петлић (члан подмлатка спортског } \\
\text { друштва, СН) })^{12}, \text { слоница (девојка која ради } \\
\text { преко везе, РЖ), бумбар (утицајна личност, } \\
\text { РЖ/РСЖ), лав/лаф (човек који има успеха } \\
\text { у друштву, РСАНУ), лавица/лафица (женс- } \\
\text { ка особа која има успеха у мушком друштву, } \\
\text { РСАНУ) })^{13}\end{array}$ \\
\hline
\end{tabular}

4.2. Примећујемо да се зоонимским метафорама конотативно маркирају припадници полиције, криминалних група, припадници војске, школства, казнених установа, што не треба да изненађује с обзиром на то да је у пи-

\footnotetext{
${ }^{9}$ Pres je utvrdio da je Milikić, već kao ,,gušter” u prvom mesecu vojnikovanja, samo sedam dana nakon položene zakletve putovao u Strazbur (rts.rs, 27.1.2009). (СрпКор 2013)

${ }^{10} \mathrm{Kad}$ sam već raskrvavljen pao na zemlju, prišao treći, gorila i repetirao na mene automatsko oružje (Политика, 11.10.2000). (СрпКор 2013)

${ }^{11}$ Poznatiji i kao bezimeni menadžer, uspešan biznismen, ajkula Vol strita (Политика, 27.11.2008). (СрпКор 2013)

${ }^{12}$ U predigri glavnog meča, od 18 . 30 časova, sastaće se „petlići” (1991 . godište) Crvene zvezde i Rudara iz Kosovske Mitrovice (Политика, 29.5.2001). (СрпКор 2013)

${ }^{13}$ Oni se najzad behu sreli, laf i lafica, oboje puni čežnje, ona sita svoga poštenog braka, on željan jednog događaja (Бранимир Ћосић, Два царства). (СрпКор 2013)
} 
тању жаргонски регистар, а да се жаргон реализује као језички варијетет који служи за комуникацију унутар неке друштвено одређене групе (в. Бугарски 2003: 9), било да је у питању потреба за језичким „прикривањем” у деловима вокабулара кримогених група, било да су у питању професије чије чланове повезује заједнички интерес, као што је то војска.

4.3. По речима Ј. Јовановић, језичка слика света показује да говорници српског језика имају изразито негативан став и презрив емотивни однос према полицијској професији, посебно према носиоцима нижих полицијских звања/чинова. ${ }^{14}$ И анкетни тип истраживања потврђује нам да је „најстереотипније занимање у српској лингвокултуролошкој заједници полищајащ” (Николић 2018: 149). ${ }^{15}$ Негативно конотиран однос према припадницима полиције, оличен у секундарним значењима зоолошких назива, представља социјалну димензију употребе жаргона и потврђује отпор корисника овог нестандардног језичког варијетета према симболичким представницима извршне власти. Припадници полиције углавном се доводе у везу са животињама из категорије паса (кер, керавац, иукела, пас), чиме се потврђује да у српском друштву преовлађује негативна репрезентација пca на вредносној скали људског односа према животињама (в. Новокмет 2016), за шта узрок можемо тражити у различитим друштвеним и религијским факторима.

Семантичке компоненте понашања - 'прождрљиво митско биће, неман' у структури лексеме ала, 'птица злослутница' у лексеми гавран и 'птица грабљивица која највише уништава птице певачице' у лексеми кобац предодредили су негативну конотираност секундарних жаргонских значења ових лексема која се у жаргону такође односе на припаднике полиције у различитим чиновима (инспектор, милиционар). Традиционална негативна конотираност лисице и глодара (као штетних животиња) такође утиче на то да се ови зооними жаргонски употребљавају за представнике полиције у нижим чиновима (милиционар, линијски милиционар, позорник, улични полицајац и сл.).

4.4. Припадници криминалних група номинују се преко представника животињског света на основу неке изразите карактеристике која доминира у њиховом изгледу или карактеристичне црте животињског понашања. Тако се 'шеф криминалне групе' назива ајкулом ${ }^{16}$ због диференцијалних сема које обухватају њене особине - 'снажна, крволочна, главни грабљивац у мору'.

${ }^{14} \mathrm{O}$ томе сведочи велики број синонимних лексема у овој сфери: дрот, дустабанлија, жандарак, жандарало, жандарина, жандарица, жандарчина, жача/жаио, жаџман, комесарчић, мундириија, наредничћ, пандур, пандурентина, пандурија, пандурина/пандурчина, пандурица, полицијот, прашинар, табанаш, ћошкаш, итрумф (Јовановић 2018: 359).

${ }^{15}$ Резултати анкетног истраживања преузети су из рада В. Николић (2018). Први део анкете односи се на одређивање најстереотипнијих занимања за говорнике српског језика (њих 60) који су бирали између 50 занимања. Други део анкете (у којој је учестовало 70 испитаника) захтевао је од испитаника да наведу први стереотип који им у вези са одређеним занимањем падне на памет. Испитаници су на упит о првом стеретипу који им у вези са одређеним занимањем пада на памет оставили следеће одговоре који се односе на полицајца: глуп, корумпиран, строг, подмитљив, надмен, неинтелигентан, необразован, неодговоран (И. 150).

${ }^{16}$ Грађа нам потврђује и пример у коме се ајкулом назива и 'берзански мешетар', чија је особина окрутност, немилосрдност. Иако је овај назив могуће калк из енглеског језика, његова мотивација у српском језику је прозирна. 
Имплицитне семе негативне колективне експресије које се везују за пацова и паука условљавају и секундарне реализације у виду 'пљачкаша', 'лихвара' и 'потказивача'. Сема величине активна је и у жаргонској реализацији лексеме мрав - 'ситан препродавац дроге'. Сема кретања, која подразумева специфичан начин кретања, односно скакање, активирана је у секундарној реализацији лексеме скакавач у жаргону - 'провалник који ускаче у стан кроз прозор'. Сема функције (товарна и теглећа животиња) у оквиру семантичке структуре лексеме мазга мотивисала је жаргонизовано значење 'кријумчар дроге'.

4.5. К. Хајнс (1999) на материјалу енглеског језика потврђује метафоричку концептуализацију жена као ситних животиња када се у први план истиче њихова сексуалност. Таква концептуализација последица је табуизираног односа према животињама које могу да се лове и које служе задовољењу неке човекове потребе. Такође, на тај начин изражава се и социјална дискредитација жена. У питању су најчешће мање животиње (енгл. cat, chicken / срп. мачка, пиле) које могу да се лове (енгл. grouse, fox, plover / срп. фазан, лисица, вивак), или држе као домаће животиње (енгл. pussy cat, canary, filly / срп. мацуа, канаринац, ждребица) (Хајнс 1999: 12). Најпрозирнија веза између животињских назива и особа женског пола код којих се истиче сексуална компонента у енглеском језику огледа се у случајевима када се о проституткама и јавним кућама говори као о галебовима, кунама, ждребицама, које раде у кавезима за птице, кућицама за мачке и ранчевима за пилиће (И. 14). Тако се жаргонски и у српском језику женској особи која се бави проституцијом могу дати називи из домена ситних животиња: буба, глодарка, кока, чавка, сова, цица. Такође, повезивање жена са ситним, пре свега крзненим животињама када се у први план истиче њихова полна и сексуална улога у друштву, има везе са називима за женске гениталије (па се назив преко синегдохе део за целину, преноси на женску особу). У словенском свету то су - куна, ласица, дабар и сл., док у романским језицима имамо називе ит. cavalla - коњ; ит. capra - коза; фр. chatte - мачка; фр. minou - маче (Бајдер/Ђезуато 2003: 17-18).

4.6. Ухапшеник се може назвати зебром због карактеристике светлих и тамних пруга на њеном телу, које се асоцијативно повезују са пругастом затворском одећом (изглед полазног појма). Курјак може да буде 'стражар' у затвору и строги чувар због особина крволочности, а кербер због митског наслеђа које га представља као стражара подземног света. Овакво учитавање значења у лексему кербер очиглено је културолошки и митолошки мотивисано, па тако мотиве за овакву врсту мотивације можемо тражити и у прецедентним текстовима, као што су Библија или антички митови. Врло је специфична жаргонска дефиниција за канаринца 'кажњеник под специјалном истрагом ... у логору за политичко преваспитавање на Голом Отоку' (РЖ), која се делом темељи на сегменту наше друштвено-политичке стварности, а делом на секундарној семантичкој реализацији глагола пропевати ('почети говорити истину, у истрази', РСJ), која се преко птице чија је традиционална 
карактеристика певање повезује са затвореником од кога се очекује да „цинкари".

4.7. Поред општевојног језика, који спада у тзв. професионалне (стручне) језике, у војсци постоје специјални језици другог типа - аргои, који имају пре свега експресивну функцију и оцену субјективног карактера (в. Поповић 1970: 55-57), а једна од његових посебних функција је издвајање младих од старијих војника. Тако бележимо примере као што су гуја или гуштер ('млад војник, на почетку служења војног рока') због особине зелене боје која се традиционално повезује са младошћу и неискуством, што нам потврђује лексикографска дефиниција придева зелен - 3. а. 'који није сазрео, недозрео, млад'... фиг. 'неискусан, наиван, због младости' (РСАНУ). Слаб војник се именује комарцем захваљујући физичким особинама сићушности, а Љ. Поповић бележи и пример фазан (или репоња) за младог војника (Поповић 1970: 56), који има у себи елементе потцењивања. ${ }^{17}$ Орао је 'строги војни старешина' захваљујући особинама које орла сврставају у ред супериорних птица грабљивица велике снаге и значајне митолошко-фолклорне конотације на словенском простору.

4.8. Компоненте понашања које се доживљава као агресивно, у структури лексема аждаја ('која прождире људе и животиње', РСАНУ) и звер ('назив за сисаре ... који се хране претежно месом и крвљу других кичмењака', РСАНУ) пројектују се на наставника који показује строгост и нетолеранцију према ученицима. Такође, овакав начин номинације карактеристичан је за школски жаргон.

4.9. Припадници обезбеђења називају се погрдно горилама, булдозима или мајмунима због особина њихове величине, агресивног понашања и колективне експресије која ове животиње сврстава у ред интелектуално ограничених и раздражљивих. Од свих животиња мајмун је најближи човеку са којим дели и сличан генетски материјал. Управо је та сличност са човеком извор негативне конотације у домену физичког изгледа; иако је најсличнији човеку, његова припадност животињској врсти удаљава га од човека на кључном категоријално-класификационом плану (плану врсте, или генуса), те се мајмун, појмовно и културолошки, доживљава, заправо, као изменени човек (Брем 1967: 1).

4.10. Поједине номинације, поготово оне које именују конкретна занимања, реализују се преко сема изгледа, нпр. жабом се може назвати 'ронилац са ножним перајама', а кенгуром 'поштар', преко особине ове животиње да има торбу на трбуху у којој носи младе. Особине полазних појмова темеље пренос номинације на човека у примерима као што је овца (3. фиг. 'човек одан богу', РСАНУ), захваљујући особинама кроткости и наивности које се доводе у везу с овцом, али и њеним симболичим вредностима познатим из

\footnotetext{
${ }^{17}$ У свом раду „Касарнски арго” љ. Поповић издваја још неке зоолошки мотивисане називе у војничком аргу, као што су канцеларијски пацов (војници које раде у канцеларији), папагај (везиста), комарции (ваздухопловци), лептир (онај који је свилен, плачљив) (1970: 58-60).
} 
хришћанске традиције (у којој је Христ пастир); ${ }^{18}$ папагај ('радио-водитељ који сувише често понавља назив станице'). Активирање метонимијског обрасца потврђује пример бубамара ('девојка фудбалера - према метафоричном жаргонском називу за фудбалску лопту'), тако да је ово пример лексичке метафтонимије. У ретким примерима позитивне конотације и пожељно схваћеног друштвеног понашања, лав (лаф), односно лавица (лафица) $)^{19}$ представљају мушкарца, односно жену који се добро сналазе у друштву, који су успешни у друштву супротног пола. ${ }^{20}$

4.11. Одређеним зоонимским примерима изражава се вредносно ниподаштавајући однос према одређеним типовима друштвеног понашања или друштвеног статуса, тј. положаја који се сматрају непожељним, па бележимо да је слоница 'девојка одн. жена која конкурише за посао, а има везу' (негативна конотација према животињи која се види као крупна, неспретна и сл.), док је бумбар, због семе величине, 'утицајна, моћна личност'.

4.12. Стереотипи у вези са одређеним народима и националним припадностима углавном изостају у оваквом преносу номинације, осим ако у обзир не узмемо и традиционалне начине исхране које практикују поједини народи, а који наилазе на негативну интерпретацију других култура и називе из творбено-семантичке категорије nomina agentis у ширем смислу (тако постоје називи жабари, односно мачкари за Италијане, тј. Далматинце) $)^{21}$. Називи делфини или орлови за припаднике националних домаћих репрезентација (у ватерполу и фудбалу) одлика су пре симболичких вредности које те животиње имају у националној култури и део су навијачког дискурса.

\section{5. Закључна разматрања}

5.1. Као што нам примери показују, секундарна значења зоолошких лексема у жаргонској и неформалној употреби реализују махом негативне конотације које се односе на човека као социјално биће и доминантно се темеље на колективној експресији коју доводимо у везу са одређеним животињама.

\footnotetext{
${ }^{18}$ У питању су цитати, парафразе преузети из превода Библије или настали под утицајем библијских текстова; најзаступљеније животиње у Библији су овцุа, овчица и јагње као симбол плахости, нежности и кроткости.

${ }^{19}$ Хрњак (Хрњак 2014: 1-3) примећује да се у фразеологији ,,jasno očituje rod kao društveno-kulturološka kategorija" и да се жена у фразеологији поистовећује с животињама повезаним с „predodžbom o opasnosti koje one predstavljaju za čoveka”, нпр. храбра као лавица истиче женску храброст у складу са њеном традиционалном улогом мајке, али и приписују жени особине одлучности и храбрости у брањењу својих ставова, мишљења и идеала.

${ }^{20}$ Међутим, из разговорног искуства за лавицу бисмо рекли да је борбена жена, поготово она која се бори и жртвује за своје потомство. Слично нам потврђује и одломак из рада Н. Силашки: „Lavica 'lioness' was selected as the term which would be used by male respondents to refer to a strong, ambitious, persistent, self-confident, and self-sacrificing woman, devoted to her husband and children” (Силашки 2014: 327).

${ }^{21}$ Суфиксом -ар „из имена животиња изводе се називи за узгајиваче, пастире, гоничаре” и сл. (Клајн 2003: 36), док у овом конкретном случају реч је о особама које лове или једу одређене животиње.
} 
Оне су засноване на двоструким предрасудама које, превасходно, дискриминишу (или маркирају) припаднике одређених занимања и друштвених група (нпр. полиције, војске итд.), показујући критички однос према непопуларним обрасцима друштвеног понашања или друштвеног положаја (као што су непотизам, негативна селекција, директорска места, ауторитети и сл.), и, секундарно, представнике одређених животињских врста (као што је нпр. nac, глодари - пацов, одређене врсте птица - гавран, чавка, дивљих животиња - горила, звер, курјак, лисица итд.). Мотивација за овакве називе, осим у семи колективне експресије, може се наћи и у особинама физичког изгледа животиње (боја, величина и др.), њихове функције, специфичног човековог односа према њима или њиховог статуса у религији, литератури и сл. Оваквом употребом зоонима постиже се емоционално-експресивна обојеност исказа углавном унутар жаргонског регистра чији говорници показују потребу за маркирањем својих чланова, а уједно се остварује и комуникативна потреба за изражавањем негативног става према представницима одређених друштвених класа и скупина.

\section{ИЗВОРИ}

РЖ 2005: Д. Андрић, Двосмерни речник српског жаргона и жаргону сродних речи и израза, Београд: Zepter Bookwork.

PCJ 2007: Речник српскога језика, Нови Сад: Матица српска.

РСАНУ: Речник српскохрватског књижевног и народног језика, I-XX, Београд: Српска академија наука и уметности, 1959-.

РСЖ 2012: Б. Герзић, Речник српског жаргона, Београд: СА.

\section{ЛИТЕРАТУРА}

Бајдер/Ђезуато 2003: Fabienne Baider, Sara Gesuato, Masculinist Metaphors. Feminist Research, Das online Journal metaphorik.de [интернет]; доступно на: http://www.metaphorik.de/05/baidergesuato.htm.

Брем 1967: Алфред Едмунд Брем, Како живе животиње, Ријека: „Отокар Кершовани".

Бугарски 2003: Р. Бугарски, Жаргон, Београд: Библиотека XX век.

Вјежбицка 1985: A. Wierzbicka, Lexicography and conceptual analysis, Karoma, Ann Arbor.

Гортан Премк 2004: Д. Гортан-Премк, Полисемија и организација лексичког система у српском језику, Београд: Завод за уџбенике и наставна средства.

Јовановић 2018: Ј. Јовановић, Лексика погрдног значењ а у именовању човека у српском језику, Београд: Филолошки факултет [докторска дисертација].

Кјелтика/Клепарски 2005: R. Kiełtyka, G. A. Kleparski, The scope of English zoosemy: The case of DOMESTICATED ANIMALS, Studia Anglica Resoviensia 3, 76-87. 
Клајн 2003: Творба речи у савременом српском језику, Други део: суфиксаuчја и конверзија, Београд: Завод за уџбенике и наставна средства, Институт за српски језик САНУ - Нови Сад: Матица српска.

Лич 1964: E. Leach: Antropological aspects of language: Animal categories and verbal abuse, in: Eric Lenneberg (yp.), New Directions in the study of language, Cambridge, MA: MIT Press, pp. 23-63.

Лопез Родригез 2009: I. Lopez Rodriguez, Of Women, Bitches, Chickens and Vixens: Animal Metaphors for Women in English and Spanish, Culture, language and representation, 77-100.

Мартса 1999: S. Martsa, On exploring the conceptual atructure of folk knowledge: the case of animal terms, Lingustica c Filologia 9, 73-87.

Николић 2019: В. Николић, Језички стереотипи код именица којима се означавају занимања у српском језику, Стереотипът в славянските езиичи, литератури и култури, Сборник с доклади от Четиринадесетите международни славистични четения, София: Университетско издателство „Св. Климент Охридски”, 147-154.

Новокмет 2016: С. Новокмет, Метафорична значења лексема из лексичко-семантичке групе назива за псе која се односе на људске особине, Къижевност и језик, 63/1-2, 49-66.

Новокмет 2017: С. Новокмет, Метафорична значења животињских назива која се односе на човека ниске интелигенције у српском језику, Зборник Матице српске за филологију и лингвистику, 60/1, 103-119.

Поповић 1970: Љ. Поповић, Касарнски арго, Кюижевност и језик, XVII/I, $55-64$.

Ранђеловић 2012: А. Ранђеловић, Метафорична значења зоонима који се односе на људске особине, Наш језик, XLIII/3-4, 89-107.

Ристивојевић Рајковић 2008: Н. Ристивојевић Рајковић, Зоонимска метафорика о мушкарцима и женама, Philologia, бр. 6, Београд: Филолошки факултет, 45-52.

Ристивојевић Рајковић 2014: Н. Ристивојевић Рајковић, Погрдни називи за мушкарце и жене - прилог проучавању концептуализације рода, Језик, књижевност, маргинализација, Ниш: Филозофски факултет, 133-142.

Силашки 2013: N. Silaški, Animal metaphors and semantic derogation - do woman think differently from man?, Gender studies, Volume 12, Issue 1, 319-332 https://doi.org/10.2478/genst-2013-0020

Хајнс 1999: C. Hines, Foxy chicks and playboy bunnies: A case study in metaphorical Lexicalization, y: Misako K.H. (yp.) Cultural, Typological and Psychological Perspectives on Cognitive Linguistics, Amsterdam: Benjamin's, 9-23.

Хрњак 2014: A. Hrnjak, Žene, zmajevi i opasne životinje. O nekim elementima konceptualizacije žene u hrvatskoj i ruskoj frazeologiji, Zbornik Radova sa međunarodnog znanstvenog skupa „Animalistički frazemi u slavenskom jezicima. Životinje u frazeološkom ruhu”, Zagreb: Filozofski fakultet sveučilišta u Zagrebu, 1-16. 
Slobodan B. Novokmet

\section{ZOONYMS REFERRING TO HUMANS AS SOCIAL BEINGS IN SERBIAN SLENG}

\section{Summary}

The subject of this paper is a lexicological and linguo-cultural analysis of zoological lexemes (zoonyms) whose basic meanings denote animals, and whose secondary realisations refer to humans as social beings, including their professions, social status or nationality. Examples are collected through Serbian slang dictionaries and Serbian language dictionaries. The main purpose of this paper is to give an answer to the question of why zoonyms in the said categories are productive in this kind of metaphorical transformation of names and references to humans as social beings through linking a lexical-semantic analysis of examples and analysis of extra-linguistic, social, and culturological circumstances.

Key words: zoonyms, Serbian sleng, humans as social beings. 